\title{
Soundings from the Sea Floor around Cape Tyồsi in Tiba Prefecture, Central Japan.
}

\author{
Hirosi NIINO \\ (The Imperial Fisheries Institute, Tôkyô)
}

Thirty samples of bottom material were obtained by the surveying ship. of the Tiba Fisheries Experimental Station and H. I. M. S. the Komahasi from the sea floor around Cape Tyôsi. They. were put at my disposal for examination through the kindness of the staff of the Tiba Fisheries Experimental Station. The results of the examination of these samples closely agree with the bottom characters as shown in the chart No. 57 which was published in 1925 by the Hydrographic Department of the Imperial Navy. Thus, the bottom of the Tyôsi district may be divided into the following four zones according to its characters (Table I, Fig. 1).

1) Zone I. From the shore to $10 \mathrm{~m}$. bathymetric line, about $1 \mathrm{~km}$. wide, the bottom characters are very variable, consisting of rocks, gravels, coarse sands, fine sands and shells.

2) Zone II. Extends from the deeper side of zone I to the $20 \mathrm{~m}$. bathymetric line, about $3 \mathrm{~km}$. in width and consists of a fine sandy bottom. The sand grains are very angular in shape and are less than $0.18 \mathrm{~mm}$. in diameters. The constituents of the sand are quartz, feldspar, pyroxene, shell fragments, etc.

3) Zone III. The boundary between Zones II and III runs along the $20 \mathrm{~m}$. bathymetric line, but that of Zones III and IV shows no relation to the bathymetric lines. The bottom samples dredged from Zone III consist of gravels and coarse sands, sometimes intermingled with fine sands. The gravels are rounded in shape, well water-worn and not so large, for example, one measures $2 \mathrm{~cm}$. in diameter and $6 \mathrm{gr}$. in weight (Table II). The gravels consist of greywacke sandstone, chert, quarzite, shale, etc. These are the same as the characteristic rocks of the Palaeozoic System or the gravels in the Pleistocene gravel bed (Narita Series) developed at Tyôsi Peninsula ${ }^{(1,2)}$. Among the gravels dredged from Zone III, there are some that consist of soft sandstone or tuff which seems to have been derived from the Mesozoic or Tertiary System of Tyôsi Peninsula. The coarse sand in this zone consists of round quartz grains, $2 \mathrm{~mm}$. in diameter.

(1) Yamane, S.: Explanatory text of the geologieal map of Japan, Tyôsi (Zone 24, Col. IV, Sheet 110) in. 1:75.000. Imp. Geol. Surv., 1924.

(2) Yase, H.: Cretaceous stratigraphy of the Japanese Islands. The Sci. Rep. of the Tohoku Imp. Univ., 2nd series, 11 (1), 1927. 
4) Zone IV This consists of a fine sandy bottom which extends from the deeper side of Zone III and gradually changes to a muddy facies with the increase in depth. "The shape of the fine sand grains is angular and $0.17 \mathrm{~mm}$. in diameter. - Their constituent minerals are the same as those from Zone II but the quantity of each constituent mineral is quite different. It

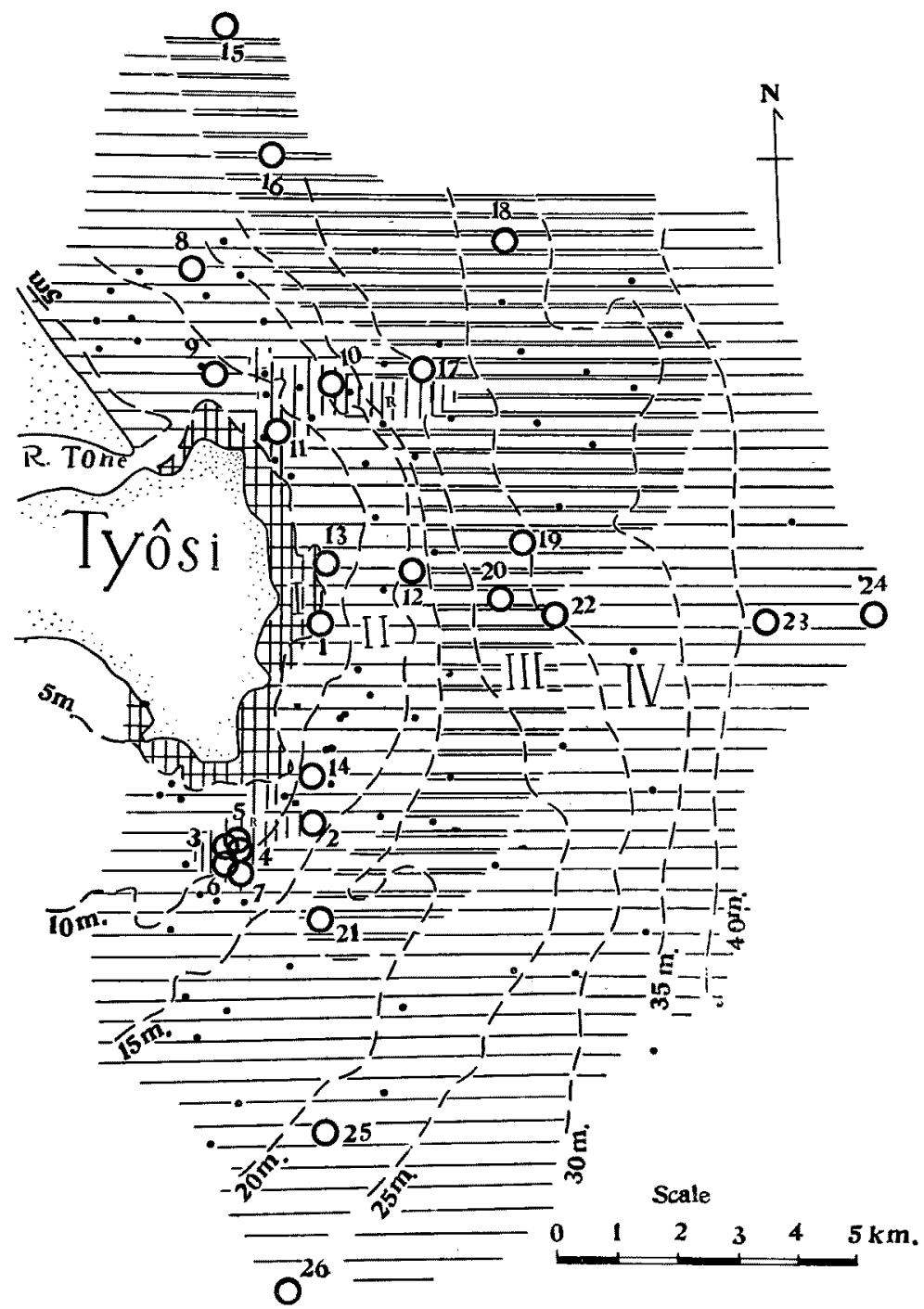

Fig. 1. Sbowing the bottom character around Cape Tyôsi in Tiba Prefecture, Central Japan I.-Zone I. Rock, gravel, coarse sand, fine sand. II.-Zone II. Fine sand. III.-Zone III. Gravel, coarse sand. IV.-Zone IV. Fine sand. $R$, Rocky bottom; -----, Bathymetric line; O, Dredged stations; •, Bottom character drawn from Chart No. 57. 
Table I The bottom samples from the dredged stations.

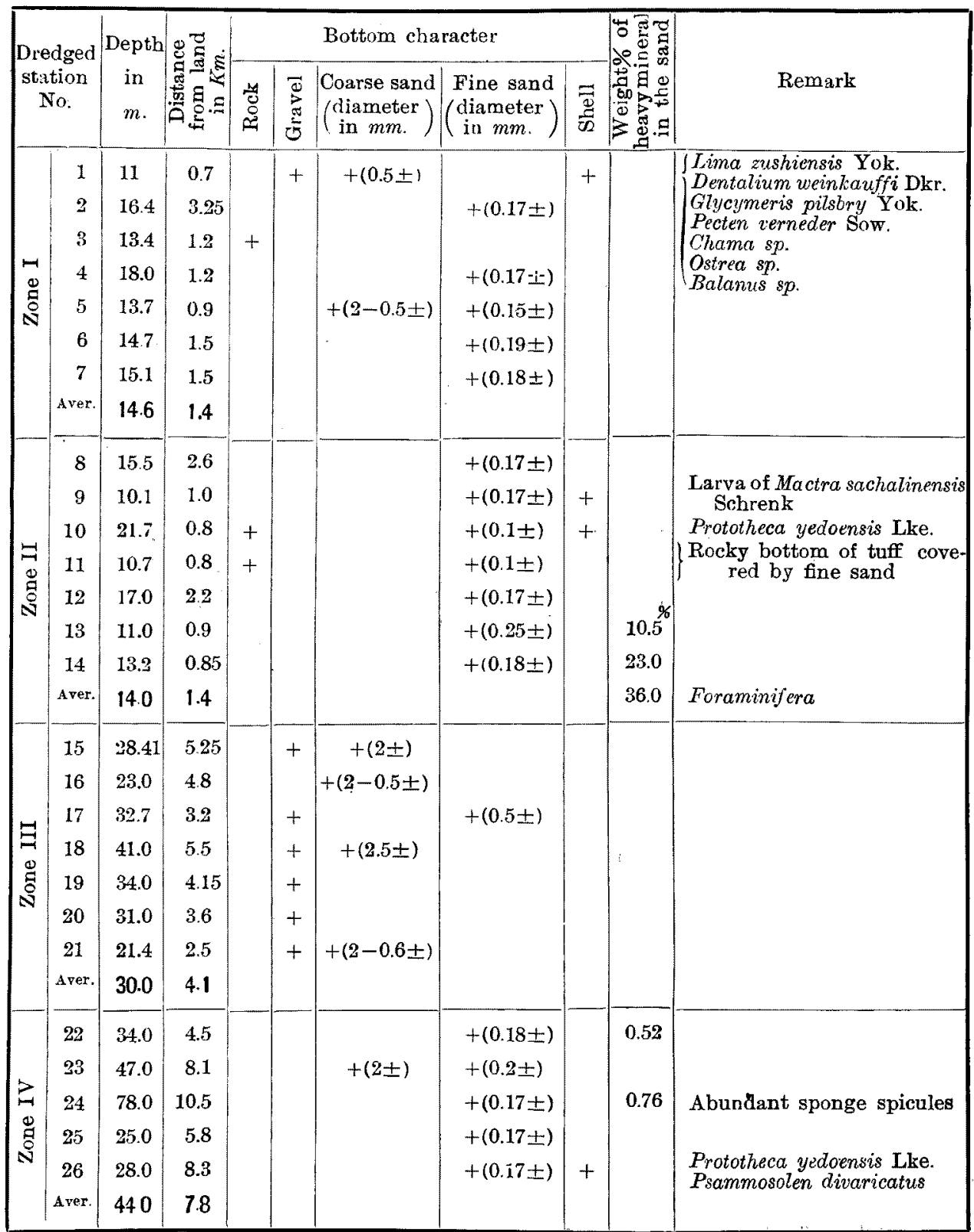


Table II Measurement of the largest pebble in each sample.

\begin{tabular}{|r|c|c|c|c|c|c|c|c|}
\hline St. & Kinds of & $\begin{array}{c}\text { Kind of } \\
\text { the } \\
\text { Neasured } \\
\text { No. }\end{array}$ & $\begin{array}{c}\text { gravel } \\
\text { gravel } \\
\text { in }\end{array}$ & $\begin{array}{c}\text { cm. } \\
\text { in } \\
\text { im. }\end{array}$ & $\begin{array}{c}\text { Thickness } \\
\text { in } \\
c m .\end{array}$ & $\begin{array}{c}\text { Weight } \\
\text { in } \\
g r .\end{array}$ & Shape & $\begin{array}{c}\text { Adhesion } \\
\text { of } \\
\text { Organism }\end{array}$ \\
\hline 1 & Ch. Q. Sh & Ch. & 1.0 & 0.7 & 0.6 & 1.0 & $\mathrm{R}$ & - \\
15 & Ss.Ch.Q.Sh & SS. & 2.74 & 1.9 & 1.3 & 8.9 & $\mathrm{R}$ & - \\
17 & Ch.Qp.Sh & Qp & 1.8 & 1.35 & 0.3 & 1.2 & $\mathrm{R}$ & - \\
18 & Ss.Ch.Lip & Lip & 1.1 & 0.9 & 0.4 & 0.7 & $\mathrm{R}$ & - \\
19 & Ch.Q.Sh & Ch & 1.3 & 1.5 & 0.7 & 1.3 & $\mathrm{R}$ & - \\
20 & Ch.Sh & Sh & 1.5 & 1.25 & 1.85 & 1.9 & $\mathrm{R}$ & - \\
\hline
\end{tabular}

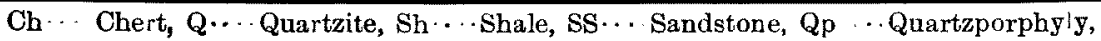
Lip.... Liparite, R... Round.

is noteworthy that, although Zone III occupies a depth greater than that of Zone II, its bottom materials are far larger than those of Zone II.

It seems to me unreasonable to assume that the large material of Zone III such as gravels and coarse sands were transported from the shore by the action of the waves or streams across Zone II which consists of very fine sands and then settled on the deep botton of Zone III. I am of the opinion that Zone III is a gravel bed ${ }^{(3)}$ which subsided in the latest geological age.

In conclusion I wish to express my sincere thanks to the staff of the Tiba Fisheries Experimental Station, especially to Mr. K. Suganuma, the director, and Mr. K. NAGAmi for kindly placing the collection of the samples at my disposal.

(3) Y $\mathrm{ABE}, \mathrm{H}$. and Aokr, R. : Geological age of the terrace along the marginal mountainland of the Kwanto tectonic basin. Geogr. Rev. Japan, 3 (2), 1928. 